\title{
PREPRINT
}

\section{Opioid Antagonism in Humans: A Primer on Optimal Dose and Timing for Central Mu-Opioid Receptor Blockade}

\author{
Martin Trøstheim ${ }^{1,2}$, Marie Eikemo ${ }^{2}$, Jan Haaker ${ }^{3}$, J. James Frost ${ }^{4}$, and Siri Leknes ${ }^{1,2}$ \\ ${ }^{1}$ Department of Diagnostic Physics, Oslo University Hospital, Oslo, Norway \\ ${ }^{2}$ Department of Psychology, University of Oslo, Oslo, Norway \\ ${ }^{3}$ Department of Systems Neuroscience, University Medical Center Hamburg-Eppendorf, Hamburg, Germany \\ ${ }^{4}$ BioMolecular Imaging, LLC, Baltimore, Maryland, USA
}

\begin{abstract}
Non-human animal studies outline precise mechanisms of central mu-opioid regulation of pain, stress, affiliation and reward processing. In humans, pharmacological blockade with nonselective opioid antagonists such as naloxone and naltrexone is typically used to assess involvement of the mu-opioid system in such processing. However, robust estimates of the opioid receptor blockade achieved by opioid antagonists are missing. Dose and timing schedules are highly variable and often based on single studies. Here, we provide a detailed analysis of central opioid receptor blockade after opioid antagonism based on existing positron emission tomography data. We also create models for estimating opioid receptor blockade with intravenous naloxone and oral naltrexone. We find that common doses of intravenous naloxone $(0.10-0.15 \mathrm{mg} / \mathrm{kg})$ and oral naltrexone $(50 \mathrm{mg})$ are more than sufficient to produce full blockade of central MOR (>90\% receptor occupancy) for the duration of a typical experimental session ( $\sim 60$ minutes), presumably due to initial super saturation of receptors. Simulations indicate that these doses also produce high KOR blockade (78-100\%) and some DOR blockade (10\% with naltrexone and 48-74\% with naloxone). Lower doses (e.g., $0.01 \mathrm{mg} / \mathrm{kg}$ intravenous naloxone) are estimated to produce less DOR and KOR blockade while still achieving a high level of MOR blockade over $\sim 30$ minutes. The models and simulations form the basis of two novel web applications for detailed planning and evaluation of experiments with opioid antagonists. These tools and recommendations enable selection of appropriate antagonists, doses and assessment time points, and determination of the achieved receptor blockade in previous studies.
\end{abstract}




\section{PREPRINT}

\section{Introduction}

A variety of psychological processes are thought to be modulated by the brain's muopioid system, including reward [1], pain [2], stress [3], and social bonding [4,5]. In studies with human participants, researchers are probing the mu-opioid system through naturally occurring variation in the mu-opioid receptor gene [6] and functional imaging of mu-opioid receptor availability with positron emission tomography (PET; [7]). These methods are however very costly due to the need for large samples (e.g., candidate gene studies) or specialized radiolabeling setups (e.g., PET). A popular method to study the mu-opioid system in humans is the pharmacological blockade of opioid receptors with antagonistic drugs. Opioid receptor antagonists bind opioid receptors, but in contrast to agonists they do not generally produce a response by the cell (although some, e.g., naloxone, may act as inverse agonists under certain conditions [8]). Opioid antagonists such as naloxone and naltrexone have a high affinity to muopioid receptors (MOR) and thereby prevent other ligands (including endogenous ones) from binding to this receptor type. Therefore, when antagonism with these drugs blocks a behavior, the behavior is assumed to be mu-opioid-dependent [9]. Most opioid antagonists available for human use are non-selective for opioid receptor subtypes and also bind to kappa-opioid receptors (KOR) with high affinity and to delta-opioid receptors (DOR) with low affinity (Table 1). To enable causal inferences about mu-opioid receptor functions based on pharmacological blockade, it is optimal to select an antagonist, a dose, and an assessment time point that results in complete blockade of MOR while causing minimal interference with other receptor types.

PET and dual-detector systems quantify in vivo receptor binding in the human brain and can be used to estimate opioid receptor blockade with non-selective opioid antagonists. Quantification of receptor binding with these techniques works by injecting a radiotracer; a ligand that binds to the target receptors in the brain and that has been labelled with a radioactive isotope. Receptor binding results in accumulation of the radiotracer in the brain. Positron emission from the radioactive isotope can then be recorded through detection of gamma rays produced by electron-positron annihilation [16-18]. Administration of an antagonist prevents the radiotracer from binding to the receptors, resulting in less accumulation of the radiotracer and fewer detected gamma rays.

Antagonist doses used in basic human research to block the mu-opioid system are often based on plasma concentration, estimates from single PET studies, or on conventions (e.g., 0.10- 


\section{PREPRINT}

$0.15 \mathrm{mg} / \mathrm{kg}$ intravenous naloxone and $50 \mathrm{mg}$ oral naltrexone), and they vary considerably. For example, reported intravenous naloxone doses used in studies of endogenous mu-opioid function are as low as $0.006 \mathrm{mg} / \mathrm{kg}$ [19] and as high as $6 \mathrm{mg} / \mathrm{kg}$ [20]. Concurrent KOR and DOR blockade is seldom considered when selecting doses. Here we synthesize the available PET and dualdetector data and create models for estimating the amount and duration of central opioid receptor blockade with various doses of commonly used opioid antagonists. In line with previous interpretations of blockade estimates, we define full blockade as $>90 \%$ receptor occupancy [21,22]. This overview will help determine the achieved MOR blockade in previous studies and evaluate the possibility of DOR and KOR blockade or carry-over effects affecting the results or complicating inferences. It will also enable selection of the appropriate antagonist drugs, doses, assessment time points and intersession intervals for future studies.

\section{Table 1}

Affinities of the opioid antagonists naloxone and naltrexone to cloned human opioid receptors expressed on Chinese hamster ovary (CHO) cells.

\begin{tabular}{lcccc}
\hline Antagonist & MOR & $\begin{array}{c}\boldsymbol{K}_{\boldsymbol{i}}(\mathbf{n M}) \\
\text { DOR }\end{array}$ & KOR & MOR:DOR:KOR \\
\hline Naloxone & & & & \\
Kelly et al. (2015) [10] & $2.09^{\mathrm{a}}$ & $30.90^{\mathrm{a}}$ & $31.62^{\mathrm{a}}$ & $1: 15: 15$ \\
Peng et al. (2007) [11] & 0.79 & 76 & 1.1 & $1: 96: 1$ \\
Toll et al. (1998) [12] & 1.4 & 67.5 & 2.5 & $1: 48: 2$ \\
Average (SE) & $1.43(0.38)$ & $58.13(13.84)$ & $11.74(9.95)$ & $1: 41: 8$ \\
\hline Naltrexone & & & $1.66^{\mathrm{a}}$ & \\
Kelly et al. (2015) [10] & $0.71^{\mathrm{a}}$ & $5.50^{\mathrm{a}}$ & 0.70 & $1: 8: 2$ \\
Konoura et al. (2015) [13] & 0.27 & 12.3 & 0.25 & $1: 16: 3$ \\
Peng et al. (2007) [11] & 0.23 & 38 & 0.40 & $1: 44: 2$ \\
Schüllner et al. (2003) [14] & 0.20 & 8.70 & 0.4 & $1: 54: 2$ \\
Toll et al. (1998) [12] & 0.2 & 10.8 & 0.19 & $1: 545: 2$ \\
Wentland et al. (2005) [15] & 0.11 & 60 & $1: 79: 2$ \\
Average (SE) & $0.29(0.09)$ & $22.55(8.88)$ & $0.60(0.22)$ & \\
\hline Note. Low & & &
\end{tabular}

Note. Lower values indicate higher affinity. $K_{i}$ is the inhibition constant, i.e., the concentration in nanomolar $(\mathrm{nM})$ required to produce half of the maximum blockade of the receptor. As such, lower numbers (i.e., concentrations) thereby indicate higher affinity for the receptor subtype. a $K_{i}$ converted from $p K_{i}$, i.e., the negative logarithm to base 10 of $K_{i}$ expressed in molar.

\section{Methods}

\subsection{Procedure}

We synthesized and further analyzed the available evidence from PET and dual-detector studies on opioid receptor blockade with naloxone and naltrexone. Studies containing blockade data were located using a semi-systematic approach, based on Web of Science searches (see Appendix) and examination of references in relevant papers. For naloxone, the shortest-acting 


\section{PREPRINT}

antagonist with the widest variety of reported doses and test schedules, we first created a loglogistic dose-response curve to map intravenous doses to MOR blockade estimates. For this model, data from 45-65 minutes post-naloxone infusions were used. A dose-response curve for oral naltrexone based on data obtained within 8 hours of administration was available from Rabiner et al. [23].

In a second step, we modeled the MOR blockade-time profile of naloxone. First, we used the reported blockade half-life in the brain with naloxone to estimate the exponential decay of receptor occupancy over time and across doses. Next, we adjusted the model to reflect the initial absorption phase (i.e., distribution to the brain) indicated by data on the time-to-peak blockade with intravenous naloxone.

Finally, due to limited availability of PET and dual-detector data, we simulated doseresponse curves for KOR and DOR blockade with naloxone and naltrexone. These simulations used MOR blockade data and relative opioid receptor affinities from studies of human opioid receptors expressed on Chinese hamster ovary (CHO) cells (see e.g., [24]). Simulation-based estimates were compared to the available PET and dual-detector data on DOR and KOR blockade with naloxone and naltrexone.

The available data on central opioid receptor blockade with nalmefene and GSK1521498 are summarized in the appendix.

\section{Results}

\subsection{Naloxone}

\subsubsection{Mu-opioid receptor blockade with intravenous naloxone}

Two PET [17,21] and two dual-detector studies [25,26] have quantified MOR blockade with intravenous naloxone. In these studies, a target dose of naloxone is first injected intravenously. Five minutes later, participants receive an intravenous injection of radiolabeled $\left[{ }^{11} \mathrm{C}\right]$ carfentanil, and positron emission from the brain is recorded for 60 minutes. The signal in the thalamus is used to calculate MOR blockade since this brain region has a very high density of mu-opioid receptors [27]. Blockade estimates in both types of studies are corrected for nonspecific binding (i.e., non-receptor binding). PET studies use the radiotracer signal in the occipital lobe as a reference for non-specific binding when correcting the blockade estimates [21] due to the small number of MOR in this region [27]. In contrast, dual-detector studies use 


\section{PREPRINT}

the thalamic radiotracer signal under $1.0 \mathrm{mg} / \mathrm{kg}$ intravenous naloxone as reference for nonspecific binding because PET studies suggest that this dose is sufficient to block nearly all MOR in the thalamus $[17,21]$.

\begin{tabular}{|c|c|c|c|c|c|}
\hline Study & Method & $\mathbf{N}$ & $\begin{array}{c}\text { Time frame } \\
\text { (minutes) }\end{array}$ & Dose & $\begin{array}{c}\text { MOR } \\
\text { blockade }\end{array}$ \\
\hline Frost et al. (1985) [17] & PET & 1 & $35-65$ & $1 \mathrm{mg} / \mathrm{kg}$ & $\begin{array}{l}83 \% \\
90 \%\end{array}$ \\
\hline Mayberg and Frost (1990) [21] & PET & --- & $45-65^{a}$ & $\begin{array}{c}0.001 \mathrm{mg} / \mathrm{kg} \\
0.01 \mathrm{mg} / \mathrm{kg} \\
0.1 \mathrm{mg} / \mathrm{kg} \\
1.0 \mathrm{mg} / \mathrm{kg}\end{array}$ & $\begin{array}{l}19 \% \\
65 \% \\
97 \% \\
98 \%\end{array}$ \\
\hline Kim et al. (1997) [25] & Dual-detector & 8 & $45-65$ & $\begin{array}{c}0.002 \mathrm{mg} / \mathrm{kg} \\
0.03 \mathrm{mg} / \mathrm{kg}\end{array}$ & $\begin{array}{l}43 \% \\
81 \%\end{array}$ \\
\hline Villemagne et al. (1994) [26] & Dual-detector & 24 & $45-65$ & $\begin{array}{c}0 \mathrm{mg} / \mathrm{kg} \\
0.0005 \mathrm{mg} / \mathrm{kg} \\
0.001 \mathrm{mg} / \mathrm{kg} \\
0.005 \mathrm{mg} / \mathrm{kg}^{\mathrm{a}} \\
0.01 \mathrm{mg} / \mathrm{kg} \\
0.1 \mathrm{mg} / \mathrm{kg} \\
0.5 \mathrm{mg} / \mathrm{kg} \\
1.0 \mathrm{mg} / \mathrm{kg} \\
\end{array}$ & $\begin{array}{c}0 \% \\
20 \% \\
40 \% \\
75 \% \\
100 \% \\
100 \% \\
100 \% \\
100 \% \\
\end{array}$ \\
\hline
\end{tabular}

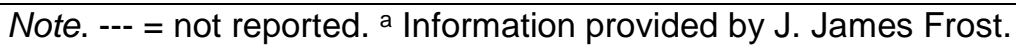

Due to the highly standardized protocol used across these studies, the data are suitable for quantitative synthesis. Based on blockade estimates from PET and dual-detector studies with $\left[{ }^{11} \mathrm{C}\right]$ carfentanil and intravenous naloxone (Table 2), and additional timing information from a PET study with intranasal naloxone [28], we created a model for estimating the level and duration of MOR blockade in the human brain achieved with various doses of intravenous naloxone.

Model specification and fitting was performed in R [29] using the drc [30] and linpk [31] packages. Our model is an adaptation of the pkprofile function from the linpk package. The pkprofile function is a general pharmacokinetic model for calculating the concentration-time profile of a drug that can account for absorption, infusion duration, and administration of multiple doses [31]. It uses a $V$ and $C l$ parameterization where $V$ is the volume of distribution and $C l$ is the clearance. $C l$ can be expressed as $k \times V$, with $k$ being the elimination rate constant. By setting $V$ to $1, C l$ defaults to $k$ and we can substitute the dose input in the pkprofile function 


\section{PREPRINT}

with the estimated MOR blockade at the administration time point $\left(t_{\text {admin }}\right)$, assuming no absorption phase. Absorption can instead be handled by the pkprofile function by specifying an absorption rate constant $\left(k_{a}\right)$.

\subsubsection{1. $\quad$ Establishing a dose-blockade curve at $\sim 55$ minutes}

Blockade estimates in available PET and dual-detector studies (Table 2) are based on the mean signal recorded between 45-65 minutes after intravenous naloxone administration. Assuming a linear decrease in blockade within this 20-minute time window (see Appendix), the reported blockade estimates approximately correspond to the blockade observed halfway (i.e., 10 minutes) through this section of the recording, i.e., at 55 minutes after intravenous naloxone administration ( $\left.t_{\text {measure }}\right)$. Like Mayberg and Frost [21], we fitted a log-logistic model to the available data (Table 2) to describe the relationship between naloxone dose and central blockade at $t_{\text {measure }}$. We specifically used a four-parameter model (Equation 1) with the lower limit constrained to 0 , the upper limit constrained to 100, and the Hill slope constrained to 1 . The parameter $E D_{50}$ (i.e., effective dose 50) in this model indicates the estimated dose at which $50 \%$ of the receptors are blocked [23].

$$
\text { Blockade }(\text { Dose })_{\text {measure }}=0+\frac{100-0}{1+\left(\frac{E D_{50}}{D o s e}\right)^{1}}=\frac{\text { Dose } \times 100}{\text { Dose }+E D_{50}}
$$

Figure 1 displays the relationship between dose and MOR blockade (in black) for intravenous naloxone $\sim 55$ minutes after administration. For the log-logistic model, we obtained the parameter estimate $E D_{50}(S E)=0.0023(0.0004)$. 


\section{PREPRINT}

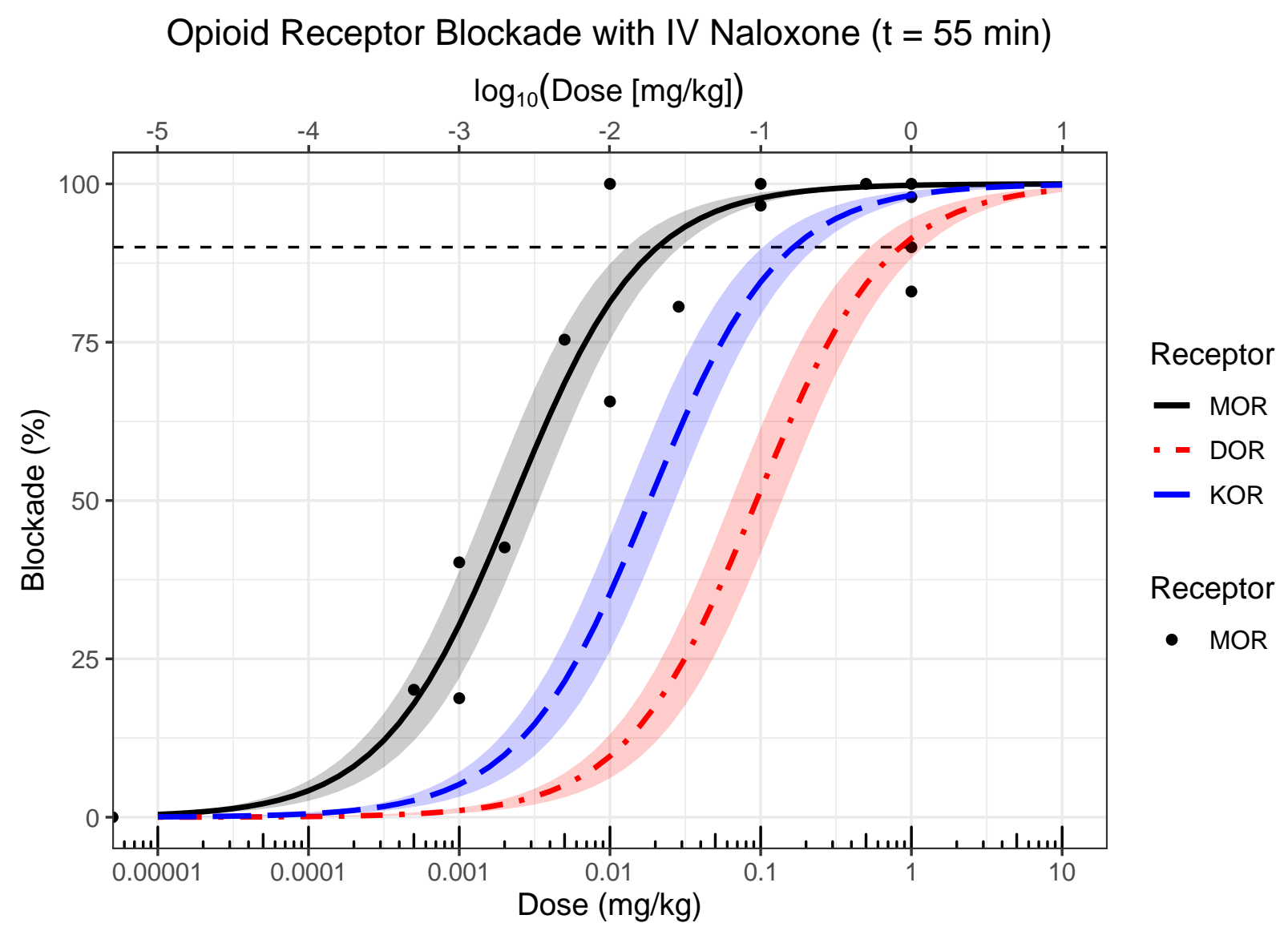

Figure 1. The effect of intravenous (IV) naloxone dose on opioid receptor blockade $~ 55$ minutes after administration. The bottom $\mathrm{x}$-axis displays untransformed doses while the top $\mathrm{x}$-axis shows the corresponding $\log _{10}$-transformed doses. The dashed horizontal line indicates full (90\%) receptor blockade. MOR blockade (solid black curve) is based on the data in Table 2 (black dots). DOR (dotdashed red curve) and KOR blockade (long-dashed blue curve) were approximated from MOR blockade using the relative receptor affinities of naloxone (Table 1). Semitransparent bands indicate $95 \%$ confidence bands. The estimated $E D_{50}$ for MOR, DOR and KOR blockade was 0.0023 ( $S E=$ $0.0004), 0.094$ and $0.018 \mathrm{mg} / \mathrm{kg}$, respectively.

\subsubsection{Establishing blockade over time}

To extrapolate the MOR blockade at the time of administration $\left(t_{a d m i n}\right)$, we followed Kim et al. [25] and used an exponential decay model (Equation 2) to first calculate the elimination rate constant $k$ from naloxone's central blockade half-life (see Appendix). The blockade half-life estimates for naloxone obtained in PET [28] and dual-detector studies [25] are 100 and 120 minutes respectively. Using an average blockade half-life of 110 minutes ( $S E=10)$, we obtained $k=0.006$. This elimination rate constant also substituted the clearance parameter $C l$ in the pkprofile function because we set the volume of distribution $V$ to 1 . 


\section{PREPRINT}

$$
\operatorname{Blockade}(t)=d \times \exp (-k \times t)
$$

In the above model, $t$ is the time in minutes after $t_{\text {measure }}$ (i.e., 55 minutes after naloxone administration) and $d$ is the dose-dependent blockade at $t_{\text {measure }}$, which can be substituted with Equation 1. By subtracting $t_{\text {measure }}$ from the time input $t$, we enable extrapolation of blockade between $t_{\text {admin }}$ (i.e., 0 minutes after naloxone administration) and $t_{\text {measure }}$ (Equation 3).

$$
\text { Blockade }(\text { Dose }, t)=\frac{\text { Dose } \times 100}{\text { Dose }+E D_{50}} \times \exp \left(-k \times\left(t-t_{\text {measure }}\right)\right)
$$

In Equation 3, $t$ indicates the time in minutes after $t_{a d m i n}$. By specifying $t=0$ in Equation 3, we get the below function (Equation 4) for calculating the blockade produced by a given dose at $t_{\text {admin }}$ assuming no absorption phase.

$$
\text { Blockade }(\text { Dose })_{\text {admin }}=\frac{\text { Dose } \times 100}{\text { Dose }+E D_{50}} \times \exp \left(-k \times\left(0-t_{\text {measure }}\right)\right)
$$

Equation 5 shows the formula for converting an intravenous naloxone dose to MOR blockade at $t_{\text {admin }}$ assuming no absorption phase. By setting the volume of distribution $V$ to 1 , we can substitute the dose input in the pkprofile function with the output of Equation 5 to enable estimation of time-blockade profiles.

$$
\text { MOR blockade }(\text { Dose })_{a d m i n}=\frac{\text { Dose } \times 100}{\text { Dose }+0.0023} \times \exp (-0.006 \times(0-55))
$$

To estimate the time-to-peak $\left(t_{\max }\right)$ blockade for intravenous naloxone, we used time series data from dual-detector studies with $\left[{ }^{11} \mathrm{C}\right]$ carfentanil $[16,25,32]$. In these studies, the maximum reduction in activity from the control condition (i.e., no naloxone) occurred 23-29 minutes after administration of intravenous naloxone $(M=24.74, S E=1.24$; see Appendix for details). These data suggest that it takes $\sim 25$ minutes after $t_{\text {admin }}$ for naloxone to be distributed to the brain and occupy a maximum amount of central MOR after a single intravenous bolus of naloxone. To obtain the absorption rate constant $k_{a}$ for the MOR blockade-time profile (see 


\section{PREPRINT}

Appendix for details), we used the Lambert $\mathrm{W}$ function ( $W_{-1}$; implemented in the pracma package; [33]). This resulted in the absorption rate constant $k_{a}=0.126$, which could be used as an input for the pkprofile function.

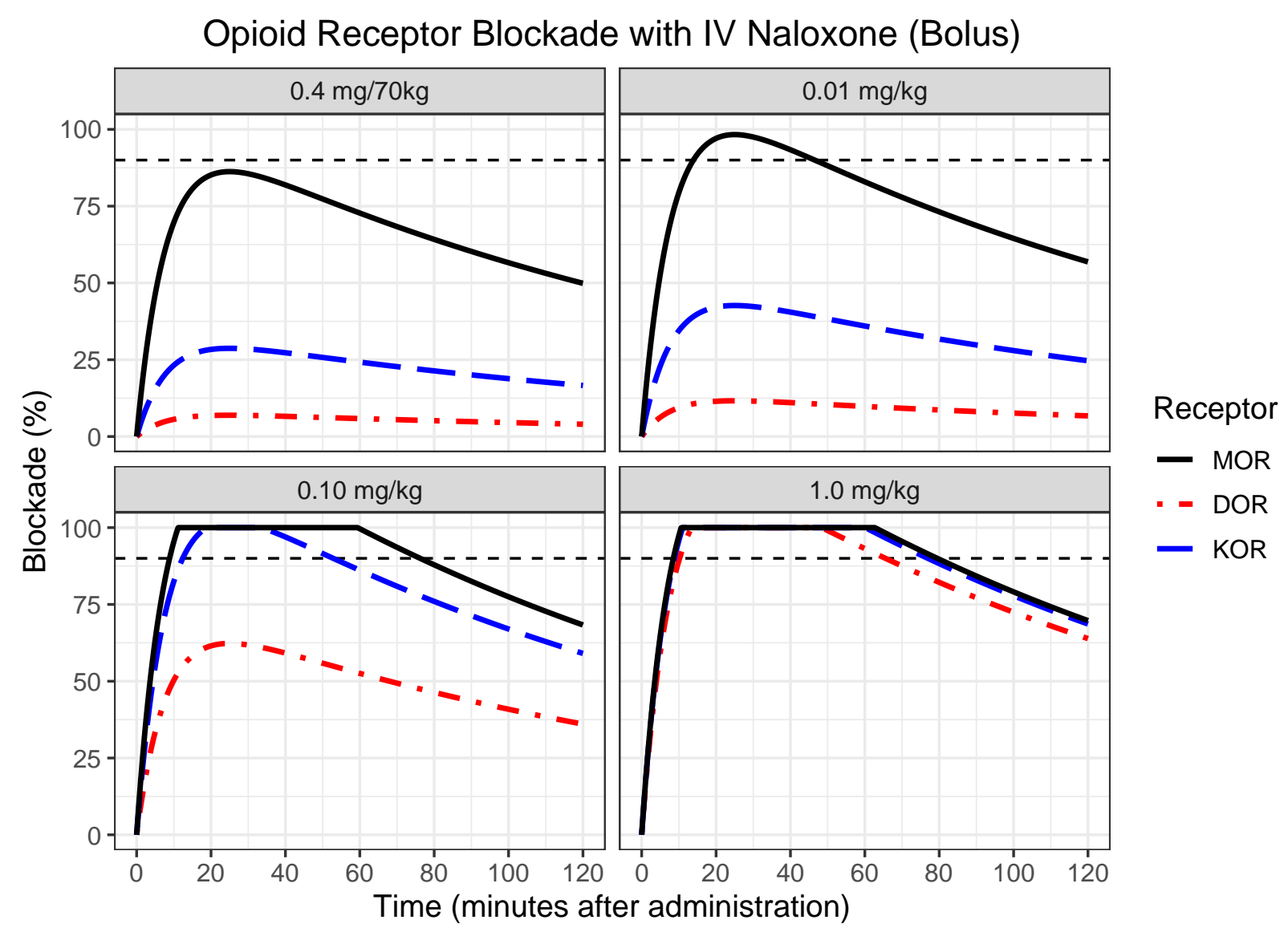

Figure 2. Time-blockade curves for exemplified bolus doses of intravenous (IV) naloxone, accounting for distribution to the brain and truncated at $100 \%$ blockade. The dashed horizontal line indicates full $(90 \%)$ receptor blockade. DOR (dot-dashed red curve) and KOR blockade (long-dashed blue curve) were approximated from MOR blockade (solid black curve) using the relative receptor affinities of naloxone (Table 1).

The final result is a model that converts an intravenous naloxone dose to central MOR blockade and computes a blockade-time profile with an absorption phase (i.e., distribution to the brain) and an elimination phase. The model treats blockade as a truncated measure of the concentration of naloxone in the brain. While blockade has an upper limit of $100 \%$, the central concentration of naloxone may exceed the level necessary to produce full blockade of mu-opioid receptors. We allowed model estimates to exceed $100 \%$ to reduce underestimation of the duration of full MOR blockade and facilitate detection of excessive concentration levels that 


\section{PREPRINT}

contribute to high DOR and KOR blockade. Blockade-time profiles for various doses of intravenous naloxone based on the model are available in Figure 2.

\subsubsection{Delta- and kappa-opioid receptor blockade with intravenous naloxone}

Naloxone is a non-selective opioid antagonists that also blocks DOR and KOR. Due to the limited data on DOR and KOR blockade with intravenous naloxone, we simulated blockade of these two receptors using data on MOR blockade and naloxone's affinity to DOR and KOR relative to MOR.

First, we generated dose-blockade curves for DOR and KOR using the estimated $E D_{50}$ for MOR blockade $(0.0023 \mathrm{mg} / \mathrm{kg})$ and the mean reported affinity of naloxone to the various human opioid receptors (Table 1). Specifically, using the relative mean affinity, we estimate that $E D_{50}$ would be 41 times greater for DOR than MOR and 8 times greater for KOR than MOR. By multiplying $E D_{50}$ for MOR blockade with naloxone's affinity to MOR relative to DOR and KOR we obtain $E D_{50}=0.094 \mathrm{mg} / \mathrm{kg}$ for DOR blockade and $E D_{50}=0.018 \mathrm{mg} / \mathrm{kg}$ for KOR blockade. Approximated dose-blockade curves for DOR and KOR at $~ 55$ minutes after intravenous naloxone administration are available in Figure 1.

Next, we established blockade-time profiles for DOR and KOR. Assuming similar elimination rate for blockade of MOR, DOR and KOR, we can adjust Equation 5 to allow for approximation of DOR (Equation 6) and KOR (Equation 7) blockade at $t_{\text {admin }}$.

$$
\begin{aligned}
& \text { DOR blockade }(\text { Dose })_{\text {admin }}=\frac{\text { Dose } \times 100}{\text { Dose }+0.094} \times \exp (-0.006 \times(0-55)) \\
& \text { KOR blockade }(\text { Dose })_{\text {admin }}=\frac{\text { Dose } \times 100}{\text { Dose }+0.018} \times \exp (-0.006 \times(0-55))
\end{aligned}
$$

If we also assume similar absorption rate for blockade of DOR and KOR as for blockade of MOR, we can use the pkprofile function to compute blockade-time profiles for DOR and KOR blockade with intravenous naloxone that incorporate an absorption phase (see Figure 2).

To validate these models, we compared the simulation results to data on DOR and KOR blockade with naloxone in humans. The available data are limited to studies using the nonselective opioid agonist $\left[{ }^{11} \mathrm{C}\right]$ diprenorphine which has equal affinity to MOR, DOR and KOR. 


\section{PREPRINT}

These studies suggest that doses of 0.1-1.5 mg/kg intravenous naloxone can completely block all three major opioid receptors [26,34]. A lower dose of $\sim 0.01 \mathrm{mg} / \mathrm{kg}$ produced full MOR blockade, but only partial blockade of DOR/KOR [26,35]. KOR blockade would likely be greater compared to DOR blockade due to naloxone's higher affinity to KOR (Table 1). Our simulations are largely consistent with the available data, showing full KOR and high DOR blockade with $0.10 \mathrm{mg} / \mathrm{kg}$ and partial DOR and KOR blockade with $0.01 \mathrm{mg} / \mathrm{kg}$ (Figure 2). However, PET studies with ligands selective to DOR and KOR are necessary to determine the differential blockade of these two receptors by intravenous naloxone.

\subsection{Naltrexone}

\subsubsection{Mu-opioid receptor blockade with oral naltrexone}

\subsubsection{1. $\quad$ Single dose}

Several studies have used PET and dual-detection systems to investigate MOR blockade with single doses of oral naltrexone. Approximately 2 hours after administration of $50 \mathrm{mg}$ oral naltrexone, the $\left[{ }^{11} \mathrm{C}\right]$ carfentanil signal in the brain matched the signal recorded 35-65 minutes after intravenous administration of $1 \mathrm{mg} / \mathrm{kg}$ naloxone [32], suggesting almost complete blockade of mu-opioid receptors [21]. Consistent with this, Rabiner et al. [23] report that $50 \mathrm{mg}$ oral naltrexone produced $95 \%$ mu-opioid receptor blockade within 8 hours after administration. The same dose maintained $>90 \%$ blockade at $\sim 49$ hours after administration in the study by Lee et al. [32]. The observed blockade in this study decreased to $80 \%$ at $\sim 73$ hours, $46 \%$ at $\sim 121$ hours, and 30\% at 169 hours after administration of naltrexone. Based on these data, Lee et al. [32] estimated the blockade half-life of naltrexone in the brain to be 72 hours. Lower doses of oral naltrexone also produce substantial levels of blockade. Within 8 hours of administration, 2, 5 and $15 \mathrm{mg}$ blocked 27, 49 and 61\% of the receptors, respectively [23]. Bednarczyk et al. [36] administered 12.5, 50 and $100 \mathrm{mg}$ oral naltrexone and measured blockade after 3, 24, 72 and 144 hours (see also [37]). The blockade estimates from this study are unfortunately unavailable.

\subsubsection{Repeated administration}

The effect of repeated naltrexone administration on mu-opioid receptor availability has been investigated with PET in abstinent alcohol dependent patients. Following four days of treatment with $50 \mathrm{mg}$ oral naltrexone, $95 \%$ of mu-opioid receptors in the brain were blocked 


\section{PREPRINT}

[22]. Similar levels of blockade have been observed after daily administration of $50 \mathrm{mg}$ oral naltrexone for three days [38].

\subsubsection{Delta- and kappa-opioid receptor blockade with oral naltrexone}

More PET data is available on DOR and KOR blockade with naltrexone than with naloxone. Applying the same simulation approach we used for intravenous naloxone to oral naltrexone, we find that simulation-based estimates largely agree with results from existing PET studies. For example, studies using the selective KOR agonist $\left[{ }^{11} \mathrm{C}\right] \mathrm{GR} 103545$ and the selective KOR antagonist $\left[{ }^{11} \mathrm{C}\right] \mathrm{LY} 2795050$ report high KOR blockade (85-93\%) in healthy participants and participants with cocaine dependence 2-3 hours after administration of $150 \mathrm{mg}$ oral naltrexone [39-41]. High levels of KOR blockade (87-92\%) have also been observed after a week of daily treatment with $100 \mathrm{mg}$ oral naltrexone in participants with alcohol dependence [24,42]. According to simulations based on data from Rabiner et al. [23] and affinity values from studies on cloned human opioid receptors (Table 1), $50 \mathrm{mg}$ oral naltrexone would block $82 \%$ of KOR (Figure 3).

Using the selective DOR antagonist N1 '-([ $\left.{ }^{11} \mathrm{C}\right]$ methyl)naltrindole $\left(\left[{ }^{11} \mathrm{C}\right] \mathrm{MeNTI}\right)$, Madar et al. [43] and Smith et al. [44] reported that a single dose of 50 and $100 \mathrm{mg}$ oral naltrexone produced $38 \%$ and 40-95\% DOR blockade (respectively) approximately 2 hours after administration in healthy volunteers. Following three and four days of treatment with $50 \mathrm{mg}$ oral naltrexone, the DOR blockade in abstinent alcohol dependent patients was estimated to $31 \%$ [38] and $21 \%$ [22], respectively. Simulations indicate that $50 \mathrm{mg}$ oral naltrexone would produce only $10 \%$ DOR blockade (Figure 3). This underestimation could result from differences in measurement time points between the Rabiner et al. study and the PET studies of DOR blockade, or from some of the latter studies using repeated administration instead of a single dose. 


\section{PREPRINT}

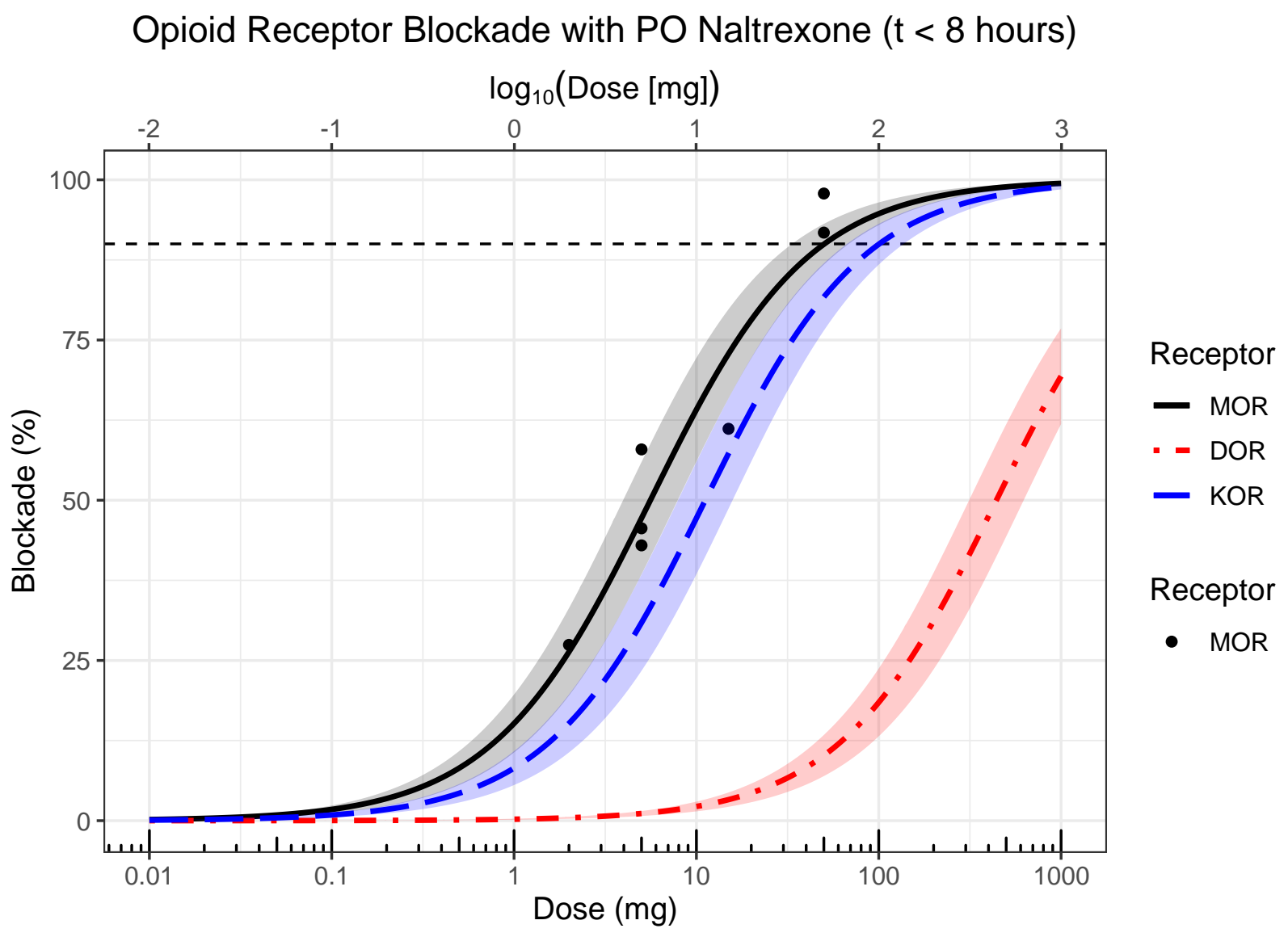

Figure 3. The effect of oral (PO) naltrexone dose on opioid receptor blockade within 8 hours of administration. The bottom $x$-axis displays untransformed doses while the top x-axis shows the corresponding $\log _{10}$-transformed doses. The dashed horizontal line indicates full (90\%) receptor blockade. MOR blockade (solid black curve) is based on data (black dots) from Rabiner et al. [23]. DOR (dot-dashed red curve) and KOR blockade (long-dashed blue curve) were approximated from MOR blockade using the relative receptor affinities of naltrexone (Table 1). Semitransparent bands indicate $95 \%$ confidence bands. The estimated $E D_{50}$ for MOR, DOR and KOR blockade was 5.59 ( $S E=$ 0.80 ; see also [23], 441.83 and $11.19 \mathrm{mg}$, respectively.

\section{General recommendations and web applications}

General recommendations for selecting optimal antagonist drugs, doses and timings in basic human research based on our models and simulations are outlined in Table 3. To simplify planning of future studies and evaluation of past studies with intravenous naloxone and oral naltrexone, we also designed two web applications using the R package Shiny [45] that incorporate the models presented here. The app for intravenous naloxone (available at https://martintrostheim.shinyapps.io/planoxone/) produces an estimated MOR blockade-time profile based on the administration time point, dose, and infusion duration of a single or multiple doses, as specified by the user. Moreover, it can calculate the average MOR blockade over a 


\section{PREPRINT}

given time interval. If provided with an intersession interval, the app will compute the residual MOR blockade at the beginning of the next session. The app for oral naltrexone (available at https://martintrostheim.shinyapps.io/plantrexone/) allows users to estimate the expected MOR blockade within 8 hours of administration of a given dose. Both apps enable users to simulate DOR and KOR blockade. By specifying the number of participants and session, and the drug price, the apps will also compute the total amount of drug needed for the study and the cost of this amount. The source code for both web applications is available on GitHub (https://github.com/martintrostheim/opioid-antagonist-planner).

Table 3

Summary and general recommendations.

\begin{tabular}{|c|c|c|}
\hline & IV naloxone & PO naltrexone \\
\hline \multicolumn{3}{|l|}{ Properties } \\
\hline Time-to-peak blockade & 25 minutes & Likely $1-2$ hours \\
\hline Blockade half-life & 110 minutes & 72 hours \\
\hline MOR:DOR:KOR affinity ratio & $1: 41: 8$ & 1:79:2 \\
\hline \multicolumn{3}{|l|}{ Recommendations } \\
\hline $\begin{array}{l}\text { Recommended doses for full } \\
(>90 \%) \text { MOR blockade }\end{array}$ & $0.01-0.15 \mathrm{mg} / \mathrm{kg}$ (bolus) & $50 \mathrm{mg}$ \\
\hline $\begin{array}{l}\text { Recommended delay } \\
\text { between administration and } \\
\text { outcome assessment }\end{array}$ & $\begin{array}{c}\text { Minimum } 15 \text { minutes with } 0.01 \\
\mathrm{mg} / \mathrm{kg} \text { (bolus). Minimum } 10 \\
\text { minutes with } 0.10-0.15 \mathrm{mg} / \mathrm{kg} \\
\text { (bolus). }\end{array}$ & Minimum 1-2 hours \\
\hline $\begin{array}{l}\text { Duration of full (>90\%) MOR } \\
\text { blockade }\end{array}$ & $\begin{array}{c}\sim 30 \text { minutes with } 0.01 \mathrm{mg} / \mathrm{kg} \\
\text { (bolus). } \sim 65 \text { minutes with } 0.10 \text { - } \\
0.15 \mathrm{mg} / \mathrm{kg} \text { (bolus). }\end{array}$ & At least 49 hours with $50 \mathrm{mg}$ \\
\hline Concurrent DOR blockade & $\begin{array}{c}\text { Low }(11-12 \%) \text { with } 0.01 \mathrm{mg} / \mathrm{kg} \\
\text { (bolus). Medium-to-high (48-74\%) } \\
\text { with } 0.10-0.15 \mathrm{mg} / \mathrm{kg} \text { (bolus) }\end{array}$ & Low (10\%) with $50 \mathrm{mg}$ \\
\hline Concurrent KOR blockade & $\begin{array}{c}\text { Medium (39-43\%) with } 0.01 \\
\mathrm{mg} / \mathrm{kg} \text { (bolus). High-to-full (78- } \\
100 \% \text { ) with } 0.10-0.15 \mathrm{mg} / \mathrm{kg} \\
\text { (bolus). }\end{array}$ & High (82\%) with 50 mg \\
\hline $\begin{array}{l}\text { Recommended intersession } \\
\text { interval for complete washout }\end{array}$ & Minimum 9 hours & Minimum 15 days \\
\hline $\begin{array}{l}\text { Recommended dose for full } \\
\text { opioid receptor blockade } \\
\text { (MOR, DOR and KOR) }\end{array}$ & 1.0 mg/kg (bolus) & $\begin{array}{c}\text { None (impractical due to the low } \\
\text { DOR affinity) }\end{array}$ \\
\hline \multicolumn{3}{|l|}{ Cost } \\
\hline Cost of druga & $\begin{array}{c}\text { One } 0.4 \mathrm{mg} / \mathrm{ml} \text { vial or ampoule: } \\
4.58-7.07 \text { USD }\end{array}$ & One $50 \mathrm{mg}$ tablet: $4.28-9.72$ USD \\
\hline $\begin{array}{l}\text { Cost of full MOR blockade } \\
\text { with bolus dose (assuming } \\
\text { the participant weighs } 70 \mathrm{~kg})^{\text {a }}\end{array}$ & $\begin{array}{c}\text { Full MOR blockade for } 65 \\
\text { minutes with } 0.1 \mathrm{mg} / \mathrm{kg}: ~ 100 \\
\text { USD. Full MOR blockade for } 30 \\
\text { minutes with } 0.01 \mathrm{mg} / \mathrm{kg}: \sim 10 \\
\text { USD. }\end{array}$ & $\begin{array}{l}\text { Full MOR blockade for up to } 49 \\
\text { hours with } 50 \mathrm{mg}: ~ 4-10 \text { USD }\end{array}$ \\
\hline
\end{tabular}




\section{PREPRINT}

\section{Discussion}

Pharmacological blockade of a receptor system is a common method for probing the function of that receptor system in the human brain. Positron emission techniques yield data on the achieved level of blockade, but for studies of mu-opioid receptors, existing practices vary widely with regards to doses and assessment timing [47]. Here, we have synthesized the available PET and dual-detector data, and created models and web applications for calculating central opioid receptor blockade with the commonly used opioid antagonists naloxone (https://martintrostheim.shinyapps.io/planoxone/) and naltrexone (https://martintrostheim.shinyapps.io/plantrexone/). Our models allow for estimation of blockade of mu- , kappa- and delta-opioid receptors over time and across relevant dosing options in human clinical and experimental research. This overview and accompanying tools can therefore facilitate selection of an appropriate antagonist drug, dose, assessment time point, and intersession interval for future studies (see Table 3 for general recommendations). Conveniently, the web applications also calculate the total amount of the antagonist drug needed for a planned study.

Pharmacokinetic modelling of opioid antagonists typically focuses on plasma levels. However, for psychopharmacological studies it is important to understand the kinetics of the antagonist in the brain. Available PET and plasma data indicate that the central receptor blockade half-life of intravenous naloxone (110 minutes) and oral naltrexone (72 hours) correspond relatively closely to the plasma half-life of these antagonists during the terminal phase (75 minutes for intravenous naloxone and 96 hours for oral naltrexone; [48,49]), but not during the distribution phase. This suggests that plasma level would be a poor proxy for receptor blockade during the distribution phase and that modelling the elimination from the brain, as approximated here, is needed inform psychopharmacological experiments in sufficient detail.

These novel analytical tools can also aid interpretation of reported effects in the literature, since the presented models yield several insights into how previously used doses affect opioid receptors at the time of assessment. This is especially useful when interpreting the literature using naloxone, which has a relatively short half-life in the brain. Bolus doses of intravenous naloxone used in basic human research are often as large as or larger than 0.10-0.15 mg/kg (e.g., [50-52]). The initial bolus is sometimes supplemented with continuous infusion or an additional bolus (e.g., [52-54]), indicating that many authors may have underestimated the duration of the 


\section{PREPRINT}

full blockade with these doses ( 60 minutes). As our model shows, such supplements are only necessary if researchers want to assess the effect of full MOR blockade on outcomes measured more than an hour after the initial bolus (see Figure 3). Yet, testing typically occurs within 15-60 minutes after the initial bolus. Lower doses are probably sufficient to produce full MOR blockade, but for a shorter period of time. For example, our model estimates $0.01 \mathrm{mg} / \mathrm{kg}$ to maintain full MOR blockade for $\sim 30$ minutes. Combining a low bolus dose with continuous infusion can greatly extend the duration of the full MOR blockade for only a fraction of the cost of a high bolus dose (Table 3). An added benefit of using lower doses is that lower doses typically yield weaker and/or fewer side effects.

Studies using naltrexone to probe the endogenous mu-opioid system often administer 50 mg orally and begin outcome assessment $~ 60-120$ minutes later (e.g., [55-58]). However, some studies use a higher dose of $100 \mathrm{mg}$ (e.g., [59,60]). The available PET and dual-detector data indicate that $50 \mathrm{mg}$ is more than sufficient to produce full MOR blockade. This dose likely produces central concentration of naltrexone in excess of the dose required to completely block mu-opioid receptors. Weerts et al. [22] observed high level of and low variability in MOR blockade with $50 \mathrm{mg}$ oral naltrexone. However, this ceiling effect could also be a result of the repeated dosing schedule used in this study. The earliest available MOR blockade estimate with oral naltrexone was collected $\sim 2$ hours after administration and indicates that waiting 2 hours is sufficient to reach full MOR blockade with $50 \mathrm{mg}$ [32]. Considering that naltrexone plasma levels peak 1 hour after oral administration [49], it is possible that the central blockade peaks in less than 2 hours.

Exponential decay processes are considered to be complete after five to ten half-lives [61]. Assuming a blockade half-life of 110 minutes with naloxone, we estimate that a washout period of 9 hours should be sufficient to eliminate the MOR blockade. This allows researchers to arrange experimental sessions on consecutive days in within-subjects designs using naloxone. In contrast, naltrexone's half-life is estimated to 72 hours. After 1 week, which is a common intersession interval for within-subjects designs with oral naltrexone (e.g., [55,56,62]), the MOR blockade with $50 \mathrm{mg}$ is reported to remain at $30 \%$. This long-lasting effect is thought to result in part from metabolites of naltrexone that also act as antagonists [63]. However, some animal and human data suggest that naltrexone's main active metabolite $6 \beta$-Naltrexol has limited ability to pass the blood-brain barrier and block central agonist effects [64]. Considering naltrexone's long 


\section{PREPRINT}

plasma terminal half-life (96 hours; [49]), it is possible that the prolonged blockade is facilitated by non-specific binding retention and/or slow release of naltrexone from central receptors. To ensure complete elimination of the blockade produced by oral naltrexone, a minimum intersession interval of 15 days would be necessary (i.e., five times the 72-hour blockade halflife; [61]).

We have primarily discussed the usefulness of intravenous naloxone and oral naltrexone in basic human research on the brain's opioid system. Intranasal formulations of naloxone are also marketed for human use. These are noninvasive and easy to apply, and may therefore represent a viable alternative to intravenous naloxone and oral naltrexone. In a PET study by Johansson et al. [28], $4 \mathrm{mg}$ of intranasal naloxone produced 85\% MOR blockade and maintained this level of blockade for at least 20 minutes. However, there was large individual variability in peak MOR blockade, perhaps due to differences in nasal physiology and administration technique [65]. The observed time-to-peak MOR blockade was 40 minutes. Due to the slow absorption phase and risk of suboptimal administration, higher intranasal doses than 4 mg may be necessary to achieve full blockade more quickly and across all subjects. We therefore recommend using intravenous naloxone and oral naltrexone over intranasal naloxone to block the endogenous opioid system in basic human research. Compared to intranasal administration, intravenous administration requires smaller doses of naloxone to quickly produce high MOR blockade and is therefore less costly. Oral naltrexone likely results in less variable MOR blockade than intranasal naloxone due to the greater reliability of the oral administration method.

Because the opioid antagonists currently marketed for human use are non-selective, there is a concern that DOR and KOR blockade could complicate inferences about MOR functions. The available data and the simulations presented here indicate that naloxone and naltrexone can produce considerable KOR and DOR blockade depending on the dose. Our results need further validation against human PET data as we used receptor affinity data from CHO cells to simulate human DOR and KOR blockade from MOR blockade. While using a lower naloxone dose could reduce DOR and KOR blockade, this comes at the cost of a shorter duration of full MOR blockade from a bolus injection (see Figure 3). Applying a range of doses optimized for each receptor type can help disentangle the effects of MOR, DOR and KOR blockade on the outcome of interest. For researchers primarily interested in the mu-opioid system, more selective 


\section{PREPRINT}

antagonists like GSK1521498 (see Appendix) could be a viable alternative to naloxone and naltrexone provided that detailed timing information becomes available.

Clinical effects of opioid antagonists can be observed without full MOR blockade. For example, the standard overdose reversal dose of intravenous naloxone (0.4 mg; [66]) starts reversing respiratory depression within 1-2 minutes, and this reversal lasts for $\sim 45-60$ minutes [67]. Our model estimates that the MOR blockade throughout the majority of this time period is 70-80\%. Regarding naltrexone, pretreatment with lower doses (estimated to produce $~ 70 \%$ MOR blockade) attenuated subjective and physiological effects of medium to large doses of hydromorphone and morphine [68,69]. Subjective and physiological effects of opioid agonists like heroin and hydromorphone begin to reemerge within 48-72 hours after large doses of naltrexone [49,70,71], when central MOR blockade is estimated to $\sim 80 \%$. Considered together, observable effects of agonist drugs on free MOR appear to emerge at 70-80\% blockade. Any endogenous functions which could be fulfilled with $20-30 \%$ or smaller amounts of available MOR have yet to be determined.

The models and recommendations presented here should be considered in light of certain limitations. Here, we have used 90\% receptor occupancy as the threshold for full blockade $[21,22]$, but we cannot exclude that the up to $10 \%$ of unblocked receptors may fulfil some endogenous functions. Furthermore, only a limited number of studies have used positron emission techniques to quantify opioid receptor blockade with antagonist drugs. Many of these studies tested a small sample of participants, and some blockade estimates are based on a dose applied to a single participant. MOR blockade estimates for large doses of naloxone and naltrexone are likely accurate due to ceiling effects. However, estimates for lower doses and estimates from late in the elimination phase may be less accurate due to large individual variability in receptor binding (e.g., [22]). Despite limited data, the reported dose and timing information for intravenous naloxone was sufficient to create a tentative model of the relationship between dose, time and blockade for this antagonist. The model builds on blockade estimates from multiple studies rather than from a single study, and it can be validated and improved with data from future PET studies.

The majority of data informing this overview and models were collected from male participants. Men and women are pharmacokinetically and pharmacodynamically different [72], and these differences might affect the opioid receptor blockade produced by antagonist drugs. 


\section{PREPRINT}

Many of the studies summarized here either present no analysis of gender effects $[21,25,26,32,35,36,38,40,43]$, tested men only $[23,34,39,73]$, or tested a single participant $[16,17]$. The few studies that report analyses of gender effects report no significant differences in receptor blockade between men and women [22,24,41,42]. Note that these studies used large doses (e.g., 50-150 mg oral naltrexone) that produce full MOR and KOR blockade in most participants. However, Weerts et al. [22] report no significant relationship between gender and the low DOR blockade produced by daily dosing of $50 \mathrm{mg}$ oral naltrexone. More data is needed determine the generalizability of our models to men and women separately.

The purpose of this primer is to help researchers select antagonist doses that can block endogenous ligands from binding to central opioid receptors. While the information synthesized here may have implications for the choice of opioid antagonist doses in future clinical research, selection of doses for treatment purposes should be based on knowledge about the relationship between opioid antagonist dose and clinical outcomes rather than blockade of endogenous ligands. Naloxone and naltrexone are competitive antagonists, meaning that higher doses of agonist drugs may overcome the blockade produced by these antagonists. Larger doses or repeated administration of opioid antagonists may therefore be necessary in treatment settings to properly block the effects of agonist drugs.

\section{Conclusion}

Pharmacological blockade of the MOR system with an antagonist such as naloxone and naltrexone is a commonly used method of investigating the role of the human mu-opioid system in psychological processes. While more data on the opioid receptor blockade produced by these antagonists are needed, we hope that this overview and the accompanying tools can aid researchers in evaluating past antagonist studies and in selecting appropriate drugs, doses, assessment time points, and intersession intervals for future studies.

\section{Acknowledgements}

This work was supported by grants from the European Research Council under the European Union's Horizon 2020 research and innovation program (grant agreement No. 802885) to Siri Leknes and the South-Eastern Norway Regional Health Authority (project No. 2018035) to Marie Eikemo. 


\section{PREPRINT}

We thank Howard Fields at the University of California San Francisco, and Molly Carlyle at the University of Oslo and The University of Queensland for feedback on the manuscript. None of the above received financial compensation outside of salary.

\section{Conflict of interest}

We declare no conflicts of interest.

\section{References}

[1] Meier IM, Eikemo M, Leknes S. The Role of Mu-Opioids for Reward and Threat Processing in Humans: Bridging the Gap from Preclinical to Clinical Opioid Drug Studies. Curr Addict Rep 2021;8:306-18. https://doi.org/10.1007/s40429-021-00366-8.

[2] Zubieta J-K, Smith YR, Bueller JA, Xu Y, Kilbourn MR, Jewett DM, et al. Regional Mu Opioid Receptor Regulation of Sensory and Affective Dimensions of Pain. Science 2001;293:311-5. https://doi.org/10.1126/science.1060952.

[3] Valentino RJ, Van Bockstaele E. Endogenous opioids: The downside of opposing stress. Stress Resil 2015;1:23-32. https://doi.org/10.1016/j.ynstr.2014.09.006.

[4] Løseth G, Ellingsen D-M, Leknes S. State-dependent $\mu$-opioid Modulation of Social Motivation - a model. Front Behav Neurosci 2014;8:430. https://doi.org/10.3389/fnbeh.2014.00430.

[5] Machin AJ, Dunbar RIM. The brain opioid theory of social attachment: a review of the evidence. Behaviour 2011;148:985-1025. https://doi.org/10.1163/000579511X596624.

[6] Mague SD, Blendy JA. OPRM1 SNP (A118G): Involvement in disease development, treatment response, and animal models. Spec Issue Contemp Adv Opioid Neuropharmacol 2010;108:172-82. https://doi.org/10.1016/j.drugalcdep.2009.12.016.

[7] Henriksen G, Willoch F. Imaging of opioid receptors in the central nervous system. Brain 2008;131:1171-96. https://doi.org/10.1093/brain/awm255.

[8] Berg KA, Clarke WP. Making Sense of Pharmacology: Inverse Agonism and Functional Selectivity. Int J Neuropsychopharmacol 2018;21:962-77. https://doi.org/10.1093/ijnp/pyy071.

[9] Eikemo M, Løseth GE, Leknes S. Do endogenous opioids mediate or fine-tune human pain relief? PAIN 2021. https://doi.org/10.1097/j.pain.0000000000002286. 


\section{PREPRINT}

[10] Kelly E, Mundell SJ, Sava A, Roth AL, Felici A, Maltby K, et al. The opioid receptor pharmacology of GSK1521498 compared to other ligands with differential effects on compulsive reward-related behaviours. Psychopharmacology (Berl) 2015;232:305-14. https://doi.org/10.1007/s00213-014-3666-3.

[11] Peng X, Knapp BI, Bidlack JM, Neumeyer JL. Pharmacological Properties of Bivalent Ligands Containing Butorphan Linked to Nalbuphine, Naltrexone, and Naloxone at $\mu, \delta$, and $\kappa$ Opioid Receptors. J Med Chem 2007;50:2254-8. https://doi.org/10.1021/jm061327z.

[12] Toll L, Berzetei-Gurske I, Polgar W, Brandt S, Adapa I, Rodriguez L, et al. Standard Binding and Functional Assays Related to Medications Development Division Testing for Potential Cocaine and Opiate Narcotic Treatment Medications. NIDA Res Monogr 1998;178:440-66.

[13] Konoura K, Fujii H, Imaide S, Gouda H, Hirayama S, Hirono S, et al. Transformation of naltrexone into mesembrane and investigation of the binding properties of its intermediate derivatives to opioid receptors. Bioorg Med Chem 2015;23:439-48.

https://doi.org/10.1016/j.bmc.2014.12.032.

[14] Schüllner F, Meditz R, Krassnig R, Morandell G, Kalinin VN, Sandler E, et al. Synthesis and Biological Evaluation of 14-Alkoxymorphinans. Part 19. Helv Chim Acta 2003;86:2335-41. https://doi.org/10.1002/hlca.200390187.

[15] Wentland MP, Lu Q, Lou R, Bu Y, Knapp BI, Bidlack JM. Synthesis and opioid receptor binding properties of a highly potent 4-hydroxy analogue of naltrexone. Bioorg Med Chem Lett 2005;15:2107-10. https://doi.org/10.1016/j.bmcl.2005.02.032.

[16] Bice AN, Wagner HN, Frost JJ, Natarajan TK, Lee MC, Wong DF, et al. Simplified Detection System for Neuroreceptor Studies in the Human Brain. J Nucl Med 1986;27:184.

[17] Frost JJ, Wagner HNJr, Dannals RF, Ravert HT, Links JM, Wilson AA, et al. Imaging Opiate Receptors in the Human Brain by Positron Tomography. J Comput Assist Tomogr 1985;9. https://doi.org/10.1097/00004728-198503000-00001.

[18] Zhang Y, Fox GB. PET imaging for receptor occupancy: meditations on calculation and simplification. J Biomed Res 2012;26:69-76. https://doi.org/10.1016/S16748301(12)60014-1. 


\section{PREPRINT}

[19] Brennum J, Kaiser F, Dahl JB. Effect of naloxone on primary and secondary hyperalgesia induced by the human burn injury model. Acta Anaesthesiol Scand 2001;45:954-60. https://doi.org/10.1034/j.1399-6576.2001.450806.x.

[20] Cutter HSG, O'Farrell TJ. Experience with alcohol and the endogenous opioid system in ethanol analgesia. Addict Behav 1987;12:331-43. https://doi.org/10.1016/03064603(87)90047-5.

[21] Mayberg HS, Frost JJ. Opiate Receptors. In: Frost JJ, Wagner Jr HN, editors. Quant. Imaging Neurorecept. Neurotransmitters Enzym., New York: Raven Press, Ltd.; 1990.

[22] Weerts EM, Kim YK, Wand GS, Dannals RF, Lee JS, Frost JJ, et al. Differences in $\delta$ - and $\mu$-Opioid Receptor Blockade Measured by Positron Emission Tomography in NaltrexoneTreated Recently Abstinent Alcohol-Dependent Subjects. Neuropsychopharmacology 2008;33:653-65. https://doi.org/10.1038/sj.npp.1301440.

[23] Rabiner EA, Beaver J, Makwana A, Searle G, Long C, Nathan PJ, et al. Pharmacological differentiation of opioid receptor antagonists by molecular and functional imaging of target occupancy and food reward-related brain activation in humans. Mol Psychiatry 2011;16:826-35. https://doi.org/10.1038/mp.2011.29.

[24] de Laat B, Nabulsi N, Huang Y, O’Malley SS, Froehlich JC, Morris ED, et al. Occupancy of the kappa opioid receptor by naltrexone predicts reduction in drinking and craving. Mol Psychiatry 2020. https://doi.org/10.1038/s41380-020-0811-8.

[25] Kim S, Wagner HN, Villemagne VL, Kao P-F, Dannals RF, Ravert HT, et al. Longer Occupancy of Opioid Receptors by Nalmefene Compared to Naloxone as Measured In Vivo by a Dual-Detector System. J Nucl Med 1997;38:1726.

[26] Villemagne VL, Frost JJ, Dannals RF, Lever JR, Tanada S, Natarajan TK, et al. Comparison of [11C]diprenorphine and [11C]carfentanil in vivo binding to opiate receptors in man using a dual detector system. Eur J Pharmacol 1994;257:195-7. https://doi.org/10.1016/0014-2999(94)90712-9.

[27] Hirvonen J, Aalto S, Hagelberg N, Maksimow A, Ingman K, Oikonen V, et al. Measurement of central $\mu$-opioid receptor binding in vivo with PET and [11C]carfentanil: a test-retest study in healthy subjects. Eur J Nucl Med Mol Imaging 2008;36:275. https://doi.org/10.1007/s00259-008-0935-6. 


\section{PREPRINT}

[28] Johansson J, Hirvonen J, Lovró Z, Ekblad L, Kaasinen V, Rajasilta O, et al. Intranasal naloxone rapidly occupies brain mu-opioid receptors in human subjects. Neuropsychopharmacology 2019;44:1667-73. https://doi.org/10.1038/s41386-019-0368-x.

[29] R Core Team. R: A language and environment for statistical computing. Vienna, Austria: R Foundation for Statistical Computing; 2020.

[30] Ritz C, Streibig JC. Bioassay Analysis using R. J Stat Softw 2005;12:1-22. https://doi.org/10.18637/jss.v012.i05.

[31] Rich B. linpk: Generate Concentration-Time Profiles from Linear PK Systems. 2021.

[32] Lee MC, Wagner HN, Tanada S, Frost JJ, Bice AN, Dannals RF. Duration of Occupancy of Opiate Receptors by Naltrexone. J Nucl Med 1988;29:1207.

[33] Borchers HW. pracma: Practical Numerical Math Functions. 2021.

[34] Sadzot B, Price JC, Mayberg HS, Douglass KH, Dannals RF, Lever JR, et al. Quantification of Human Opiate Receptor Concentration and Affinity Using High and Low Specific Activity [11C]Diprenorphine and Positron Emission Tomography. J Cereb Blood Flow Metab 1991;11:204-19. https://doi.org/10.1038/jcbfm.1991.52.

[35] Melichar JK, Nutt DJ, Malizia AL. Naloxone displacement at opioid receptor sites measured in vivo in the human brain. Eur J Pharmacol 2003;459:217-9. https://doi.org/10.1016/S0014-2999(02)02872-8.

[36] Bednarczyk EM, Wack D, Haka M, Shang Y, Hershey L, O’Sullivan R, et al. Duration of human MU opiate receptor blockade following naltrexone: Measurement by 11Ccarfentanil pet. Clin Pharmacol Ther 2005;77:P26-P26. https://doi.org/10.1016/j.clpt.2004.11.099.

[37] Okusanya OO, Amer A, Forrest A, Shang E, Bednarczyk EM. Use of PET imaging to develop a pharmacokinetic/pharmacodynamic (PK/PD) model for naltrexone (NTX) \& 6beta-naltrexol (6 beta NTX) occupancy on the human mu-opiate receptor (MOR). Clin Pharmacol Ther 2007;81:S71. https://doi.org/10.1038/sj.clpt.6100176.

[38] McCaul ME, Wand GS, Kim YK, Bencherif B, Dannals RF, Frost JJ. Naltrexone Effects on $\mathrm{Mu}$ - and Delta-Opioid Receptor Availability in Alcohol Dependence. Alcohol Clin Exp Res 2003;27:21A. https://doi.org/10.1111/j.1530-0277.2003.tb05852.x. 


\section{PREPRINT}

[39] Martinez D, Slifstein M, Matuskey D, Nabulsi N, Zheng M-Q, Lin S, et al. Kappa-opioid receptors, dynorphin, and cocaine addiction: a positron emission tomography study. Neuropsychopharmacology 2019;44:1720-7. https://doi.org/10.1038/s41386-019-0398-4.

[40] Naganawa M, Jacobsen LK, Zheng M-Q, Lin S-F, Banerjee A, Byon W, et al. Evaluation of the agonist PET radioligand [11C]GR103545 to image kappa opioid receptor in humans: Kinetic model selection, test-retest reproducibility and receptor occupancy by the antagonist PF-04455242. NeuroImage 2014;99:69-79. https://doi.org/10.1016/j.neuroimage.2014.05.033.

[41] Naganawa M, Zheng M-Q, Nabulsi N, Tomasi G, Henry S, Lin S-F, et al. Kinetic Modeling of 11C-LY2795050, A Novel Antagonist Radiotracer for PET Imaging of the Kappa Opioid Receptor in Humans. J Cereb Blood Flow Metab 2014;34:1818-25. https://doi.org/10.1038/jcbfm.2014.150.

[42] Vijay Ai, Morris E, Goldberg A, Petrulli J, Liu H, Huang Y, et al. Naltrexone occupancy at kappa opioid receptors investigated in alcoholics by PET occupancy at kappa opioid receptors investigated in alcoholics by PET. J Nucl Med 2017;58:1297.

[43] Madar I, Lever JR, Kinter CM, Scheffel U, Ravert HT, Musachio JL, et al. Imaging of $\delta$ opioid receptors in human brain by N1'- ([11C]methyl)naltrindole and PET. Synapse 1996;24:19-28. https://doi.org/10.1002/(SICI)1098-2396(199609)24:1<19::AIDSYN3>3.0.CO;2-J.

[44] Smith JS, Zubieta J-K, Price JC, Flesher JE, Madar I, Lever JR, et al. Quantification of $\delta$ Opioid Receptors in Human Brain with N1' -([11C]Methyl) Naltrindole and Positron Emission Tomography. J Cereb Blood Flow Metab 1999;19:956-66. https://doi.org/10.1097/00004647-199909000-00003.

[45] Chang W, Cheng J, Allaire J, Sievert C, Schloerke B, Xie Y, et al. shiny: Web Application Framework for R. 2021.

[46] Wishart DS, Feunang YD, Guo AC, Lo EJ, Marcu A, Grant JR, et al. DrugBank 5.0: a major update to the DrugBank database for 2018. Nucleic Acids Res 2018;46:D1074-82. https://doi.org/10.1093/nar/gkx1037.

[47] Werner MU, Pereira MP, Andersen LPH, Dahl JB. Endogenous Opioid Antagonism in Physiological Experimental Pain Models: A Systematic Review. PLOS ONE 2015;10:e0125887. https://doi.org/10.1371/journal.pone.0125887. 


\section{PREPRINT}

[48] McDonald R, Lorch U, Woodward J, Bosse B, Dooner H, Mundin G, et al.

Pharmacokinetics of concentrated naloxone nasal spray for opioid overdose reversal: Phase I healthy volunteer study. Addiction 2018;113:484-93. https://doi.org/10.1111/add.14033.

[49] Verebey K, Volavka J, Mule SJ, Resnick RB. Naltrexone: Disposition, metabolism, and effects after acute and chronic dosing. Clin Pharmacol Ther 1976;20:315-28. https://doi.org/10.1002/cpt1976203315.

[50] Bruehl S, Burns JW, Chung OY, Ward P, Johnson B. Anger and pain sensitivity in chronic low back pain patients and pain-free controls: the role of endogenous opioids. PAIN 2002;99:223-33. https://doi.org/10.1016/S0304-3959(02)00104-5.

[51] Buchel C, Miedl S, Sprenger C. Hedonic processing in humans is mediated by an opioidergic mechanism in a mesocorticolimbic system. ELife 2018;7:e39648. https://doi.org/10.7554/eLife.39648.

[52] Eippert F, Bingel U, Schoell ED, Yacubian J, Klinger R, Lorenz J, et al. Activation of the Opioidergic Descending Pain Control System Underlies Placebo Analgesia. Neuron 2009;63:533-43. https://doi.org/10.1016/j.neuron.2009.07.014.

[53] Berna C, Leknes S, Ahmad AH, Mhuircheartaigh RN, Goodwin GM, Tracey I. OpioidIndependent and Opioid-Mediated Modes of Pain Modulation. J Neurosci 2018;38:9047. https://doi.org/10.1523/JNEUROSCI.0854-18.2018.

[54] Julien N, Marchand S. Endogenous pain inhibitory systems activated by spatial summation are opioid-mediated. Neurosci Lett 2006;401:256-60.

https://doi.org/10.1016/j.neulet.2006.03.032.

[55] Bruehl S, Carlson CR, Wilson JF, Norton JA, Colclough G, Brady MJ, et al. Psychological coping with acute pain: An examination of the role of endogenous opioid mechanisms. $\mathrm{J}$ Behav Med 1996;19:129-42. https://doi.org/10.1007/BF01857603.

[56] Eikemo M, Løseth GE, Johnstone T, Gjerstad J, Willoch F, Leknes S. Sweet taste pleasantness is modulated by morphine and naltrexone. Psychopharmacology (Berl) 2016;233:3711-23. https://doi.org/10.1007/s00213-016-4403-x.

[57] Inagaki TK, Hazlett LI, Andreescu C. Naltrexone alters responses to social and physical warmth: implications for social bonding. Soc Cogn Affect Neurosci 2019;14:471-9. https://doi.org/10.1093/scan/nsz026. 


\section{PREPRINT}

[58] Meier IM, Bos PA, Hamilton K, Stein DJ, van Honk J, Malcolm-Smith S. Naltrexone increases negatively-valenced facial responses to happy faces in female participants. Psychoneuroendocrinology 2016;74:65-8. https://doi.org/10.1016/j.psyneuen.2016.08.022.

[59] Charles SJ, Farias M, van Mulukom V, Saraswati A, Dein S, Watts F, et al. Blocking muopioid receptors inhibits social bonding in rituals. Biol Lett 2020;16:20200485. https://doi.org/10.1098/rsbl.2020.0485.

[60] Tarr B, Launay J, Benson C, Dunbar RIM. 'Naltrexone Blocks Endorphins Released when Dancing in Synchrony.' Adapt Hum Behav Physiol 2017;3:241-54. https://doi.org/10.1007/s40750-017-0067-y.

[61] Byers JP, Sarver JG. Chapter 10 - Pharmacokinetic Modeling. In: Hacker M, Messer W, Bachmann K, editors. Pharmacology, San Diego: Academic Press; 2009, p. 201-77. https://doi.org/10.1016/B978-0-12-369521-5.00010-5.

[62] Yeomans MR, Gray RW. Effects of Naltrexone on Food Intake and Changes in Subjective Appetite During Eating: Evidence for Opioid Involvement in the Appetizer Effect. Physiol Behav 1997;62:15-21. https://doi.org/10.1016/S0031-9384(97)00101-7.

[63] Schmidhammer H. Opioid Receptor Antagonists. In: Ellis GP, Luscombe DK, Oxford AW, editors. Prog. Med. Chem., vol. 35, Elsevier; 1998, p. 83-132. https://doi.org/10.1016/S0079-6468(08)70035-3.

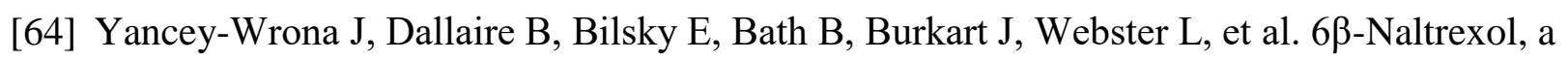
Peripherally Selective Opioid Antagonist that Inhibits Morphine-Induced Slowing of Gastrointestinal Transit: An Exploratory Study. Pain Med 2011;12:1727-37. https://doi.org/10.1111/j.1526-4637.2011.01279.x.

[65] Pires A, Fortuna A, Alves G, Falcão A. Intranasal Drug Delivery: How, Why and What for? J Pharm Pharm Sci 2009;12:288-311. https://doi.org/10.18433/J3NC79.

[66] Connors NJ, Nelson LS. The Evolution of Recommended Naloxone Dosing for Opioid Overdose by Medical Specialty. J Med Toxicol 2016;12:276-81. https://doi.org/10.1007/s13181-016-0559-3.

[67] Evans JM, Hogg MIJ, Lunn JN, Rosen M. Degree and Duration of Reversal by Naloxone of Effects of Morphine in Conscious Subjects. Br Med J 1974;2:589. https://doi.org/10.1136/bmj.2.5919.589. 


\section{PREPRINT}

[68] Martin WR, Jasinski DR, Mansky PA. Naltrexone, an Antagonist for the Treatment of Heroin Dependence: Effects in Man. Arch Gen Psychiatry 1973;28:784-91. https://doi.org/10.1001/archpsyc.1973.01750360022003.

[69] Preston KL, Bigelow GE. Differential naltrexone antagonism of hydromorphone and pentazocine effects in human volunteers. J Pharmacol Exp Ther 1993;264:813.

[70] Navaratnam V, Jamaludin A, Raman N, Mohamed M, Mansor SM. Determination of naltrexone dosage for narcotic agonist blockade in detoxified Asian addicts. Drug Alcohol Depend 1994;34:231-6. https://doi.org/10.1016/0376-8716(94)90161-9.

[71] Walsh SL, Sullivan JT, Preston KL, Garner JE, Bigelow GE. Effects of naltrexone on response to intravenous cocaine, hydromorphone and their combination in humans. $\mathrm{J}$ Pharmacol Exp Ther 1996;279:524.

[72] Soldin OP, Mattison DR. Sex Differences in Pharmacokinetics and Pharmacodynamics. Clin Pharmacokinet 2009;48:143-57. https://doi.org/10.2165/00003088-200948030-00001.

[73] Ingman K, Hagelberg N, Aalto S, Någren K, Juhakoski A, Karhuvaara S, et al. Prolonged Central $\mu$-Opioid Receptor Occupancy after Single and Repeated Nalmefene Dosing. Neuropsychopharmacology 2005;30:2245-53. https://doi.org/10.1038/sj.npp.1300790. 